\title{
EDUKASI PERPAJAKAN: UNDANG-UNDANG KETERBUKAAN INFORMASI KEUANGAN SEBAGAI SARANA MEMBANGUN KESADARAN BAYAR PAJAK MELALUI PENDIDIKAN PERGURUAN TINGGI YOGYAKARTA
}

\author{
Alfiatul Maulida ${ }^{1}$ \& Siti Sumartiah ${ }^{2}$ \\ Universitas Sarjanawiyata Tamansiswa Yogyakarta ${ }^{12}$ \\ Email : alfiatulmaulida@ustjogja.ac.id ${ }^{1}$
}

\begin{abstract}
The large number of people who avoid taxes has made the government look for effective and efficient alternatives to enforce an orderly and legally correct manner, namely by issuing the Law on the Disclosure of Financial Information. The Law on Financial Information Disclosure was published on 23 August 2017. Access to financial information for tax purposes includes access to receive and obtain financial information in the context of implementing the provisions of laws and regulations in the field of taxation and the implementation of international tax treaties. This study aims to analyze how much influence tax education can have on building tax awareness, to analyze how much the Financial Information Disclosure Act is known and understood by prospective taxpayers and taxpayers, and to analyze the effect of the Law on the Disclosure of Financial Information to make Personal Taxpayers. pay taxes orderly. The research method used is Path Analysis.
\end{abstract}

Keywords: tax education, disclosure of financial information, tax compliance funds

\section{Pendahuluan}

Pajak merupakan sarana untuk mendekatkan manusia yang satu dengan manusia yang lain dalam bentuk kewajiban berbagi. Kewajiban membayar pajak merupakan salah satu bentuk komunikasi nonverbal dalam artian saling berbagi kepada sesama yang mempunyai penghasilan lebih kepada yang penghasilnya kurang dri cukup bahkan pribadi yang belum bekerja. Dana pajak berguna untuk kehidupan masyarakat yang paling realistik untuk mengelola kehidupan lebih baik dan sejahtera. Selain untuk kesejahteraan bersama, dana pajak juga digunakan untuk pembangunan. Hasil pajak didistribusikan kepada pemerintah pusat dengan 
nama APBN dan kepada daerah atas nama APBD. Anggran ini digunakan negara untuk pembangunan infrastruktur maupun yang lainnya.

Banyaknya masyarakat yang menghidari pajak membuat pemerintah mencari alternatif yang efektif dan efisien untuk memaksa secara tertib dan benar menurut hukum, yaitu dengan menerbitkan Undang-Undang Keterbukaan Informasi Keuangan. Undang-Undang keterbukaan Informasi Keuangan di terbitkan pada 23 Agustus tahun 2017. Akses informasi keuangan untuk kepentingan perpajakan meliputi akses untuk menerima dan memperoleh informasi keuangan dalam rangka pelaksanaan ketentuan peraturan perundangundangan di bidang perpajakan dan pelaksanaan perjanjian internasional di bidang perpajakan. Misalkan, jasa keuangan dari sektor perbankan, pasar modal, perasuransian, lembaga jasa kuaangan lainnya (UU KIK No. 01 tahun 2017). Adanya Undang-Undang tersebut diharapkan agar wajib pajak pribadi tidak menghidar untuk membayar pajak dan jendral pajak dapat mengetahui siapa saja yang harus membayar pajak.

Kesadaran memebayar pajak tidak bisa langsung datang secara tiba-tiba untuk membayar pajak karena pada dasarnya manusia mempunyai sifat homo homini lupus yang mana manusia mempunya sifat yang serakah sehingga intruksi membayar pajak dan disertakan denda-denda bahkan sanksi secara pidana pun masih kurang akurang atau tidak dapat merubah sifat tersebut. Merubah mindset tersebut bisa dilakukan dengan cara membeirkan edukasi di perguruan tinggi, tempat dimana para calon wajib pajak atau wajib pajak mempercayai dan menghargai arahan dari seorang guru atau disebut dosen. Hal ini akan sangat membantu para direktorat jendral pajak untuk membangun sadar bayar pajak sejak dini. Edukasi pendidikan bisa dilakukan secara tersruktur dengan menjadwal kan pendidikan pajak dan sebelumnya, pihak pajak bisa bekerja sama dengan pihak institusi agar dijadwalkan matakuliah tersebut.

Sosialisasi dan pendidikan pajak akan lebih mudah untuk membangun kesadaran membayar pajak. Didalam pendidikan, akan terbentuklah sebuah kebiasaan mencatat, menghitung, dan bahkan menganalisan pajak yang harus dibayarkan. Kebiasaan tersbut akan menjadi karakter bagi calon wajib pajak 
maupun wajib pajak. Karakter yang dibangun tersebut akan memberikan dampak positif terhadap lingkungannya sehingga calon wajib pajak maupun wajib pajak akan memberikan pengaruh positif terhadap teman sekitar dan akhirnya bagi masyarakat Indonesia.

Pemberian edukasi perpajakan akan lebih efektif jika dimulai dari suatu komunitas kecil atau individu yang bergabung mempelajari pajak. Hal ini bisa dimulai dari perguruaan tinggi yang ada di Indonesia, misalnya di Daerah Istimewa Yogyakarta. Daerah ini merupaka kota pendidikan ssehingga dengan gelar ini akan mudah di percayai mahasiswa disana bahwa pendidikan pajak untuk sadar akan bayar pajak sangan akan membantu negara. Banyaknya perguruan tinggi di Yogyakarta membuat pendidikan perpajakan akan sangat efektif tapi pemberian pendidikan perpajakan harus dimulai dari satu persatu institusi. Misalkan di Universitas Sarjanawiayata Tamansiswa.

\subsection{Rumusan Masalah}

Rumusan masalah dari penelitian ini adalah a) Apakah edukasi perpajakan dapat membangun kesadaran bayar pajak?, b) Apakah Undang-Undang Keterbukaan Informasi Keuangan Sudah diketahui dan dipahami Calon Wajib Pajak dan Wajib Pajak?, dan c) Apakah Undang-Undang Keterbukaan Informasi Keuangan bisa Membuat Wajib Pjak Membayar Pajak?

\subsection{Tujuan Khusus}

Untuk menganalisa seberapa besar pengaruh edukasi perpajakan dapat membangung kesadaran bayar pajak, Untuk menganalisa seberapa banyak Undang-Undang Keterbukaan Informasi Keuangan diketahui dan dipahami calon Wajib Pajak maupun Wajib Pajak, dan Untuk menganalisa pengaruh UndangUndang Keterbukaan Informasi Keuangan membuat Wajib Pajak Pribadi tertib bayar pajak. 


\subsection{Manfaat dan Urgensi Penelitian}

Hasil penelitian yang diperoleh diharapkan dapat memberikan manfaat : a) Secara praktis, hasil penelitian ini diharapkan dapat memberikan masukan kepada pimpinan Pajak Pratama Indonesia dalam rangka pengambilan keputusan (Making decision) baik untuk jangka panjang dan jangka menengah maupun jangka pendek, b) Hasil penelitian diharapkan dapat memberikan pengertian dan pemahaman terhadap wajib pajak akan pentingnya sadar akan bayar pajak untuk operasional negara dan masyarakat secara keseluruhan,

Pelakasanaan peneltian ini merupakan hal yang sangat urgen untuk dilakukan. Hal ini di akibatkan masih banyaknya para masyarakat terutama masyarakat produktif yang berada dibangku kuliah yang merasa kurang pentingnya membayar pajak secara tepat waktu.

\section{Tinjauan Pustaka}

\section{Definisi Pajak}

Pajak dapat diartikan sebagai iuran wajib oleh masyarakat kepada negara dan mereka wajib membayarnya menurut peraturan, tanpa mendapatkan mendapatkan kontraprestasi secara langsung, memiliki sifat memaksa, dan digunakan untuk membiayai pengeluaran yang berkaitan dengan pemerinta serta untuk kemakmuran bersama (Purwono, 2010). Pajak merupakan iuran rakyat kepada kan negara berdasarkan undang-undang (yang dapat dipaksakan) dengan tiada mendapat jasatimbal (kontraprestasi), yang langsung dapat ditujukan dan yang digunakan untuk membayar pengeluaran umum (Mardiasmo, 2018). Pajak adalah iuran kepada Negara yang terutang oleh wajib pajak menurut peraturan-peraturan atau dapat dipaksakan, dengan tidak mendaapat prestasi kembali, yang langsung dapat ditunjukkan dan yang gunakanya adalah untuk membiayai pengeluaran-pengeluaran umum berhubungan dengan tugas Negara yang menyelenggrakan pemerintah (Halim Abdul, Icuk Rangga B, 2014). 


\section{Kepatuhan Pajak}

Kepatuhan wajib pajak adalah suatu keadaan wajib pajak dimana dia memenuhi semua hal yang menajadi kewajiban kewajiban perpajakannya dan melaksanakan hakhak pajak yang dia dapat (Alviansyah, 2011). Kepatuhan perpajakan diartikan sebagai suatu keadaan dimana wajib pajak patuh dan mempunyai kesadaran dalam membayar pajak berdasarkan Peraturan Mentri Keuangan Nomor 192/PMK.03/2007,wajib pajak patuh adalah wajib pajak yang ditetapkan oleh direktur jenderal pajak sebagai Wajib Pajak yang memenuhi kriteria tertentu.

Kepatuhan wajib pajak merupakan rasa bersalah dan rasa malu, persepsi wajib pajak atas kewajaran dan keadilan beban pakak yang mereka tanggung, dan pengaruh kepuasan terhadap pelayanan pemerintah (Mardiasmo, 2018). Derajat atau tingkat kepatuhan dapat diukur dari adanya tag gap, yaitu perbedaan antara apa yang tersurat dalam aturan perpajakan dengan apa yang dilaksanankan oleh seorang wajib pajak (Hamongan, 2012).

\section{Edukasi}

Secara umum dapat dikatakan semakin tinggi tingkat pendidikan waib pajak semakin mudak bagi mereka untuk memahami segala sesuatu yang berhubungan dengan pajak termasuk peraturan-peraturan perpajakan (Nurmantu, 2005).

\section{Faktor-faktor yang mempengaruhi kepatuhan wajib pajak}

Faktor yang mendorong kepatuhan wajib pajak terdiri dari faktor pengetahuan/pemahaman wajib pajak dan faktor psikologi Wajib Pajak. Faktor pengetahuan wajib pajak terdiri dari pengetahuan atas hokum pajak materiil dan hokum pajak formil, sedangkan faktor psikologi wajib pajak dipengaruhi oleh sosialisasi perpajakan, pelayanan perpajakan, dan pemeriksaan perpajakan (Rahman, 2009). Pengetahuan wajib pajak berhubungan erat dengan kepatuhan pajak. Pengetahuan perpajakan merupakan pemahaman wajib pajak mengenai hokum, undang-undang, tatacara perpajakan yang benar (Ihsan, 2013). 
Semakin tinggi tingkat pendidikan Wajib Pajak maka semakin mudah bagi mereka untuk memahami peraturan perpajakan, ternasuk memahami sanksi administrasi dan sanksi pidana perpajakan. Namun rumitnya peraturan perpajakan mangakibatkan tidak semua wajib pajak yang berpendidikan tinggi memahami dan mengetahui peraturan perpajakan, sehingga tingkat pengetahuan dan pemahaman mengenai hukum dan tatacara perpajakan menjadi rendah (Knut Eriksen, 1996).

\section{Pengembangan Hipotesis}

\section{Pengaruh Undang-Undang Keterbukaan Informasi Keuangan Terhadap Kesadaran Bayar Pajak}

Pengetahuan wajib pajak tentang UU Keterbukaan Informasi Keuangan akan mempengaruhi kesadaran wajib pajak untuk membayar pajak. Menurut Trisia dan Haryanto (2006) adanya pengetahuan UU Keterbukaan Informasi Keuangan akan memebuat wajib pajak patuh dan malakukan kewajibannya. Awlia dan Siringoringo (2019) berpendapat bahwa Undang-Undang Keterbukaan Informasi Keuangan berpengaruh positif signifikan terhadap kepatuhan Wajib pajak dalam membayar pajak. Hipotesisi ini juga didukung oleh penelitian Azizah (2015), meningkatnya kepatuhan membayar pajak didasari oleh pengetahuan wajib pajak.

\section{Pengaruh Undang-Undang Keterbukaan Informasi Keuangan Terhadap Kesadaran Bayar Pajak Melalui Edukasi Perpajakan}

Awlia dan Siringoringo (2019) berpendapat bahwa Undang-Undang Keterbukaan Informasi Keuangan berpengaruh positif signifikan terhadap kepatuhan Wajib pajak dalam membayar pajak. Hipotesisi ini juga didukung oleh penelitian Azizah (2015), meningkatnya kepatuhan membayar pajak didasari oleh pengetahuan wajib pajak. Pengaruh UU KIK akan sangat tersebar apabila adanya informasi tersebut di lakukan sejak dini dari calon wajib pajak menempuh pendidikan. Hal ini didukung oleh beberapa penelitian yaitu, 


\section{Pengaruh Edukasi Perpajakan Terhadap Kesadaran Bayar Pajak}

Masalah utama perpajakan adalah minimnya pengetahuan wajib pajak mengenai hak dan kewajibannya sebagai wajib pajak. Diperlukan pemahaman yang tinggi dari wajib pajak untuk mewujudkan selfassessment system. System ini memberikan wajib pajak kepercayaan dan tanggungjawab sepenuhnya mengisi SPT, yaitu untuk menghitung, menyetor, dan melaporkan sendiri jumlah pajak (Ongkowijoyo, 2010). Edukasi perpajakan memberikan pengaruh terhadap kesadaran membayar pajak, hal ini dibuktikan oleh penelitian.

\section{Kerangka Konseptual}

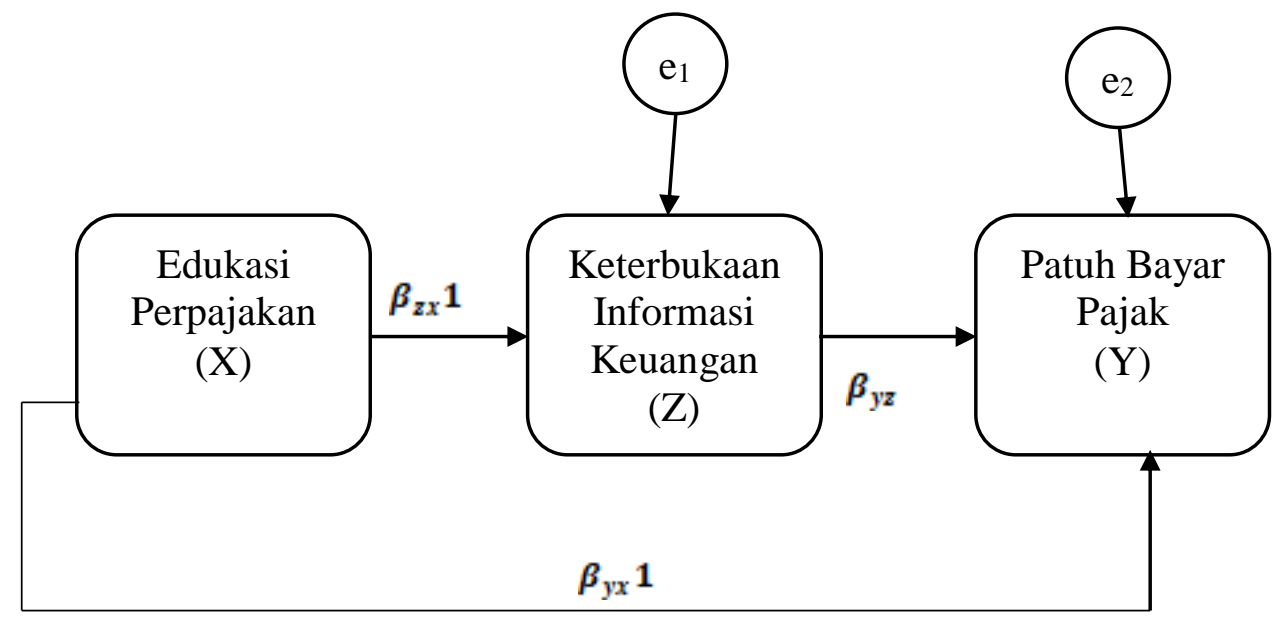

Gambar. 2.1. Kerangka Konseptual

\section{Metode Penelitian}

\subsection{Desain Penelitian}

Fenomena umum yang sering terjadi di negara berkembang adalah adanya wajib pajak yang tidak sadar akan pentingnya bayar pajak untuk meningkatkan kebutuhan bersama bahkan sengaja untuk tidak membayar dengan alasan-alasan tertentu. Melalui Pengetahuan wajib pajak tentang UU Keterbukaan Informasi Keuangan akan mempengaruhi kesadaran wajib pajak untuk membayar pajak. Adanya pengetahuan UU Keterbukaan Informasi Keuangan akan memebuat wajib pajak patuh dan malakukan kewajibannya (Trisia dan Haryanto, 2006), (Awlia dan Siringoringo, 2019), dan (Azizah, 2015) yang diharapkan dapat memberikan kepastian tentang pemberian edukasi perpajakan yang ada di tingkat Perguruan Tinggi. Penelitian ini merupakan 
jenis penelitian kuantitatif. Data kuatitatif adalah penelitian berdasarkan pada filsafat positifme, digunakan untuk meneliti populasi atau sampel tertentu, pengumpulan data menggunakan instrument penelitian, analisis data bersifat statistik dengan tujuan untuk menguji hipotesis (Sugiyono, 2012:13). Penelitian ini bermaksud untuk menjelaskan kedudukan variabel-variabel yang diteliti serta hubungan antara satu variabel dengan yang lain, maka rancangan penelitian ini adalah penelitian eksplanatori (explanatory research) (Sugiyanto, 2012:21).

\subsection{Populasi, sampel, dan teknik pengambilan sampel}

Populasi adalah wilayah generalisasi yang terdiri atas obyek atau subyek yang mempunyai kualitas dan karakteristik tertentu yang ditetapkan oleh peneliti untuk dipelajari dan kemudian ditarik kesimpulannya (Sugiyono, 2012:115). Populasi penelitian ini adalah semua mahasiswa universitas Sarjanawiyata Tamansiswa Yogyakarta. Sampel penelitian in adalah mahasiswa Fakultas Ekonomi dari seluruh angkatan dengan menggunakan teknik pengambilan sampel convenience sampling.

\subsection{Sumber dan Jenis Data}

Penelitian ini menggunakan sumber data primer yang diperoleh melalui survey.

\subsection{Teknik Pengumpulan Data}

Pengumpulan data menggunakan data primer, dengan instrument kuisioner menggunkana 5 point skala linkert.

\subsection{Teknik Analisis Data}

\subsubsection{Uji Normalitas Data}

Tujuan dari uji normalitas data adalah untuk mengetahui apakah regresi, variabel endogen, variabel eksogen atau kedua-duanya mempunyai distribusi data normal atau mendekati abnormal (Santoso, 2004:212). Uji normalitas dilakukan dengan menggunakan Kolmogorov-smirnov tets dengan menetapkan derajat keyakinan $(\alpha) 1 \%$, $5 \%$, atau $10 \%$. Uji ini dilakukan pada setiap variabel dengan ketentuan bahwa jika secara individu masing masing variabel tersebut juga bias dinyataka memenuhi asumsi 
normalitas. Caranya dengan menentukan terlebih dahulu hipotesis pengujian, yaitu :

$\mathrm{H}_{0}$ : data berdistribusi normal.

$\mathrm{H}_{\mathrm{a}}$ : data tidak berdistribusi normal.

Selanjutnya menentukan kriteria pengujian ini dengan melihat barisan Kolmogorov-smirnov tets adalah sebagai berikut:

a. jika $p$-value $\geq(\alpha)$ maka data tersebut berdistribusi normal atau $\mathrm{H}_{0}$ ditolak;

b. jika $p$-value $\leq(\alpha)$ maka data tersebut tidak berditribusi normal atau $\mathrm{H}_{0}$ diterima.

Alternatif solusi yang dapat dilakukan jika data tidak berdistribusi normal yaitu mengubah nilai variabel menggunakan Z-score

\subsubsection{Analisis Jalur (Path)}

Menurut Dillon dan Goldstein (1984), analisis jalur adalah pengembangan dari model regresi yang digunakan untuk menguji bentuk hubungan sebab akibat atau kausal dari beberapa variabel dan kesesuaian dari model tersebut. Dengan path analysis, dapat diestimasi koefisien-koefisien beberapa persamaan struktural linear yang mempunyai hubungan sebab akibat seperti yang sudah dihipotesiskan.

Menurut Dillon dan Goldstein (1984) dan Hair et al. (1998), dalam menggunakan analisis path dibutuhkan beberapa asumsi yang harus diteliti antara lain :

a. model-model analisis path berasumsi bahwa variabel eksogen dan variabel endogen minimal terukur dalam skala interval,

b. hubungan antara variabel adalah linear,

c. semua error diasumsikan tidak terkorelasi dengan variabel endogennya,

d. hanya model satu arah yang diperbolehkan, variabel eksogen diukur tanpa error.

\subsubsection{Uji Asumsi Klasik}

Uji asumsi klasik dilakukan untuk mengetahui penyimpangan yang terjadi pada data penelitian agar model path bersifat BLUE (Best Linier Unbiased Estimated). Asumsi klasik yang digunakan pada penelitan ini yaitu: uji normalitas model, uji multikolinieritas, Autokorelasi, dan Heteroskedastisitas yang secara rinci dijelaskan sebagai berikut: 


\section{a. Uji Multikolinieritas}

Multikolinieritas merupakan adanya hubungan linier diantara beberapa atau semua variabel independen pada model penelitian. Uji ini menentukan apakah pada model penelitian ditemukan hubungan linier antar variabel independen atau tidak. Cara mengetahui ada tidaknya multikolinieritas pada model dilakukan pendeteksian terlebih dahulu, kemudian jika multikolinieritas terjadi, barulah dilakukan tindakan untuk menghilangkan efek dari multikolinieritas (Gujarati, 2004:342-363).

Adapun cara untuk mengukur ada tidaknya multikolinieritas dapat dilihat dari nilai Tolerance (TOL) dan Variance Inflation Factors (VIF) dari masing masing variabel. Jika nilai VIF > 10 maka terjadi multikolinieritas dan sebaliknya (Gujarati, 2004).

Apabila terjadi multikolinieritas, cara mengatasinya adalah menggunakan tranformasi variabel ke dalam bentuk Logaritma Natural.

\section{b. Uji Autokorelasi}

Uji autokorelasi digunakan untuk mengetahui ada tidaknya penyimpangan asumsi klasik, autokorelasi yaitu menguji korelasi yang terjadi antara residual pada satu pengamatan lain terhadap model regresi. Gejala autokorelasi dapat berakibat hasil regresi tidak efisien karena varian atau standart error of estimate tidak minimum dan menjadikan tes signifikansi tidak akurat. Cara mengetahui apakah model regresi mengandung autokorelasi dapat digunakan pendekatan Durbin Watson Test (Gujarati, 2004) dengan kriteria sebagai berikut:

a. Apabila $d_{U} \leq \mathrm{DW} \leq 4-d_{U} . \mathrm{H}_{0}$ diterima, artinya tidak terdapat autokorelasi pada model tersebut.

b. Apabila DW $<d_{L} . \mathrm{H}_{0}$ ditolak, artinya terdapat autokorelasi pada model tersebut.

c. Apabila $\left(d_{L} \leq \mathrm{DW} \leq d_{U}\right)$ atau $\left(4-d_{L} \leq \mathrm{DW} \leq 4-d_{U}\right)$. Uji hasilnya konklusif, sehingga tidak dapat ditentukan apakah terdapat autokorelasi atau tidak.

Apabila terjadi autokorelasi, maka dapat diperbaiki dengan tindakan memasukkan variabel lag dari variabel terikatnya menjadi salah satu variabel bebas, sehingga data observasi menjadi berkurang 1. 


\section{c. Uji Heteroskedastisitas}

Pengujian heteroskedastisitas adalah untuk menguji apakah dalam sebuah model regresi terjadi kesalahan penganggu yang mempunyai varian yang sama atau tidak. Pengujian ini menggunakan Glejser dengan langkah-langkah sebagai berikut (Gujarati, 2004:438):

a. Melakukan regersi variabel terikat $(\mathrm{Y})$ terhadap variabel bebas $(\mathrm{X})$ dan memperoleh nilai absolut residual.

b. Melakukan regersi variabel dari nilai absolut residual (lel) terhadap variabel bebas (X) dengan bentuk regresi sebagai berikut:

$$
\begin{aligned}
& \text { (lel) } Z=a_{0}+a_{0} X_{1}+a_{2} X_{2}+a_{3} X_{3}(\text { model } 1) \\
& \text { (lel) } Y=a_{0}+a_{0} X_{1}+a_{2} X_{2}+a_{3} X_{3}+a_{4} Z_{4}(\text { model } 2)
\end{aligned}
$$

c. Menentukan ada tidaknya heterokedastisitas dalam uji statistik untuk menguji hipotesis : $H_{a}: \mu=0$ dan $H_{i}: \mu \# 0$

Kriteria pengambilan keputusan:

1) Apabila $p$-value $\geq a$, maka dalam model tidak terjadi heteroskedastisitas.

2) Apabila $p$-value $\leq a$, maka dalam model terjadi heteroskedastisitas.

Apabila terjadi Heteroskedastisitas, maka dapat diperbaiki dengan tindakan mentranformasi variabel yang terkena heteroskedastisitas kedalam bentuk logaritma $(\log 10)$.

\subsubsection{Uji Hipotesis}

\section{a. Uji t (Uji Parsial)}

Uji ini dilakukan untuk mengetahui pengaruh dari variabel independen terhadap variabel dependen secara parsial. Langkah - langkah dalam melakukan uji t yaitu: 1) Formulasi Hipotesis

Hipotesis nol (Ho) yang bersifat netral atau dapat juga di definisikan suatu pernyataan tentang parameter yang bertentangan dengan keyakinan peneliti atau

kebalikan Ha. Bunyi hipotesisnya sebagai berikut:

$\mathrm{Ho}_{1}=$ Tidak ada pengaruh edukasi perpajakan terhadap KIK

$\mathrm{Ho}_{2}=$ Tidak ada pengaruh edukasi perpajakan terhadap kepatuhan membayar 
pajak

$\mathrm{Ho}_{3}=$ Tidak ada pengaruh KIK terhadap patuh bayar pajak

Hipotesis alternatif merupakan anggapan dasar peneliti terhadap suatu masalah yang sedang dikaji bersifat tidak netral. Sehingga bunyi hipotesisnya:

$\mathrm{Ha}_{1}=$ ada pengaruh edukasi perpajakan terhadap KIK I

$\mathrm{Ha}_{2}=$ ada pengaruh edukasi perpajakan terhadap kepatuhan membayar pajak

$\mathrm{Ha}_{3}=$ ada pengaruh KIK terhadap patuh bayar pajak

2) Menentukan Risiko Kesalahan (Taraf Signifikansi)

Tahap ini adalah tahap untuk menentukan seberapa besar peluang membuat risiko kesalahan mengambil keputusan menolah hipotesis yang benar. Taraf signifikansi yang digunakan pada penelitian ini adalah $\alpha=1 \%, 5 \%$ dan $10 \%$. Pemilihan tingkat signifikansi di dasarkan pada tingkat signifikansi yang sesuai dengan kepentingan dan tujuan penelitian.

3) Penarikan keputusan hipotesis

Ketentuan ditolak atau diterimanya $\mathrm{H}_{0}$ adalah sebagai berikut

a) $p$-value $>\alpha$, maka $\mathrm{H}_{0}$ diterima

b) $p$-value $<\alpha$, maka $\mathrm{H}_{0}$ ditolak dan $\mathrm{H}_{\mathrm{a}}$ diterima.

\section{Hasil Dan Pembahasan}

\subsection{Gambaran Umum Obyek Penelitian}

Universitas Sarjanawiayata Tamansiswa (UST) Yogyakarta merupakan salah satu perguruan tinggi yang terletak di Kota Yogyakarta. UST Yogyakarta juga merupakan 10 besar kampus terbaik di Yogyakarta. Kampus tersebut memiliki banyak program studi salah satunya adalah Program Studi Manajemen dimana pada program studi manajemen dipelajari tentang perpajakan bagi mahasiswa.

Obyek dalam penelitian ini adalah mahasiswa Program Studi Manajemen dari angkatan 2016-2019. Dari total keseluruahan mahasiswa yang memenuhi sampling yang ditetapkan, maka diperoleh 254 mahasiswa yang menjadi sampel penelitian ini. Daftar Mahasiswa yang memenuhi kriteria yang telah ditetapkan dapat dilihat pada table berikut: 


\begin{tabular}{|c|c|c|}
\hline No & Email & Nama \\
\hline 1 & fadhillaajeng120@gmail.com & Fadhilla Ajeng Aqdella \\
\hline 2 & yuliendaryani@gmail.com & Yuli Endar Yani \\
\hline 3 & yesiginting@gmail.com & Yesi Eliana Br Ginting \\
\hline 4 & istonhurint15@gmail.com & Paskalis K D Hurint \\
\hline 5 & araminthajacindap@yahoo.com & Aramintha Jacinda Puteri \\
\hline 6 & farisarya71@gmail.com & Faris Arya Wiratama \\
\hline 7 & muhwadi81253@gmail.com & Muh.Hasban Wadi \\
\hline 8 & alfianahmad382@gmail.com & Ahmad Alfian Ihsan \\
\hline 9 & hayatiwawan@gmail.com & Wawan Ardiyanto Ardi \\
\hline 10 & ajikurniawati52@gmail.com & Aji Kurniawati \\
\hline 11 & gianscoops1@gmail.com & Gian Aulia Arman \\
\hline 12 & rianafatma016@gmail.com & Sakti Riana Fatmaningrum \\
\hline 13 & Rediarjuna06@gmail.com & Redi Arjuna \\
\hline 14 & alfianijatiningsih1@gmail.com & Alfiani Jatiningsih \\
\hline 15 & niaanisa234@gmail.com & Nia Anisachturohmah \\
\hline 16 & iswanthepashter22@gmail.com & Tri Iswanto \\
\hline 17 & fiasuwistiningtyas@gmail.com & Fia Suwistiningtyas \\
\hline 18 & rewidyasela97@gmail.com & Bekti Rewidya Oktalisela \\
\hline 19 & laelatu1557@gmail.com & Siti Laelatul Qodriyah \\
\hline 20 & ninayuliyanti93@gmail.com & Nina Yuliyanti \\
\hline
\end{tabular}

\subsection{Data Penelitian}

Variabel independen penelitian ini adalah Edukasi Perpajakan. Data yang digunakan berupa Nilai dari kuisioner elektronik (Google Form) selama periode penelitian tahun 2020. Variabel Intervining yaitu Keterbukaan Informasi Keuangan menggunakan data Nilai dari kuisioner elektronik (Google Form) selama periode penelitian tahun 2020. Variabel dependen penelitian ini adalah Patuh Bayar Pajak. Data yang digunakan yaitu Nilai dari kuisioner elektronik (Google Form) selama periode penelitian tahun 2020. Data variabel dependen ditunjukkan pada Lampiran 2, Lampiran 3 dan Lampiran 4 serta Lampiran 5.

\subsection{Analisis Hasil Penelitian}

Penelitian ini, analisis data menggunakan statistik deskriptif dan analisis jalur. Statistik deskriptif menggunakan data-data nilai minimal, maksimal, rata-rata dan deviasi standar, sedangakan tujuan dari penggunaan analisis jalur ialah untuk mengtahui 
pengaruh langsung dan tidak langsung pada suatu variabel endogen, variabel intervining, dan eksogen. Sebelum analisis jalur dilakukan terlebih dahulu dilakukan uji statistik deskriptif, uji normalitas data dan uji asumsi klasik, baik itu normalitas residual, multikolinieritas, heteroskedastisitas, dan autokorelasi. Cara mengetahui pengaruh antara variabel independen dan variabel dependen menggunakan uji hipotesis.

\subsubsection{Hasil Statistik Deskriptif}

Statistik deskriptif bertujuan mendeskripsikan data penelitian berdasarkan nilai maksimum dan minimum, nilai rata-rata, serta deviasi standar. Penelitian ini menggunkana 1 variabel independen yaitu Edukasi Perpajakan. Variabel Intervining 1 yaitu Keterbukaan Informasi Keuangan (KIK). Variabel independen 1 yaitu Patuh Bayar Pajak. Statistik deskriptif ditunjukkan pada tabel berikut:

Tabel 4.2

Statistik Deskriptif $(n=254)$

\begin{tabular}{lllll}
\hline Variabel & Minimal & Maksimal & Rata-rata & Dev Std \\
\hline Edu_Pjk (\%) & 1.00 & 5.00 & 4.2126 & .69126 \\
KIK (\%) & 1.00 & 5.00 & 4.3850 & .63936 \\
Pth_Bayar_Pjk (\%) & 1.00 & 5.00 & 3.4457 & .58637 \\
\hline
\end{tabular}

Sumber : Lampiran 6

Pada Tabel 4.2 dapat diketahui bahwa nilai Edukasi Perpajakan, Keterbukaan Informasi Keuangan, dan Patuh Bayar Pajak minimal adalah 1\% sedangakan maksimal Edukasi Perpajakan, Keterbukaan Informasi Keuangan, dan Patuh Bayar Pajak adalah 5\% selama periode penelitian. Artinya, selama periode pengamatan semua variable memiliki nilai terndah $1 \%$ dan tertinggi 5\%. Nilai rata-rata Edukasi Perpajakan 4\%, Keterbukaan Informasi Keuangan 4\%, dan Patuh Bayar Pajak sebesar 3\% sedangkan nilai deviasi standar Edukasi Perpajakan 0.69\%, Keterbukaan Informasi Keuangan $0.64 \%$, dan Patuh Bayar Pajak sebesar $0.58 \% \%$. Hal ini mengidentifikasi penyebaran data yang bagus karena nilai rata-rata lebih tinggi dari pada standar deviasi. 


\subsubsection{Uji Normalitas Data}

Tujuan dari uji normalitas data adalah untuk mengetahui apakah regresi, variabel endogen, variabel eksogen atau kedua-duanya mempunyai distribusi data normal atau mendekati abnormal (Santoso, 2004:212). Uji normalitas dilakukan dengan menggunakan Kolmogorov-smirnov tets dengan menetapkan derajat keyakinan ( $\alpha$ ) 1\%, $5 \%$, atau $10 \%$. Uji ini dilakukan pada setiap variabel dengan ketentuan bahwa jika secara individu masing masing variabel tersebut juga bias dinyataka memenuhi asumsi normalitas. Hasil uji normalitas data disajikan pada Tabel 4.3 :

\section{Tests of Normality}

\begin{tabular}{|c|c|c|}
\hline & & \\
\hline & tic & tic \\
\hline $\begin{array}{l}\text { ayar_Pjk } \\
\text { Pjk }\end{array}$ & & \\
\hline
\end{tabular}

er : Lampiran 7

Pada Tabel 4.3, Variabel Edukasi Perpajakan, Keterbukaan Informasi Keuangan, dan Patuh Bayar Pajak menunjukkan bahwa semua nilai variabel kurang dari atau lebih rendah dari 0.05 , sehingga dapat dikatakan bahwa semua data variabel tidak berdistribusi normal. Sehingga perlu dilakukan perbaikan dengan menggunakan tranformasi data.

Data penelitian yang tidak berdistribusi normal ditransformasi terlebih dahulu agar menjadi normal. Menormalkan variabel, model path dirubah dalam bentuk menggunakan Z-Score (lihat Lampiran 6).

\subsubsection{Persamaan Path}

Dari data sekunder yang diperoleh kemudian dilakukan analisis path yang selanjutnya akan menghasilkan persamaan path untuk masing-masing variabel dependen. Analisis jalur digunakan untuk menguji besarnya kontribusi yang ditujukan oleh koefisien jalur dari hubungan kausal antar variabel Edukasi Perpajakan, Keterbukaan Informasi Keuangan, dan Patuh Bayar Pajak, juga digunakan sebab akibat 
yang terjadi jika variabel independennya mempengaruhi variabel dependenya tidak hanya secara langsung melainkan juga secara tidak langsung. Setelah dilakukan analisis data, selanjutnya dibuat model persamaan path-nya dengan melihat tabel 4.4 berikut:

Tabel 4.4 Model Path Untuk Model 1 dan Model 2

\begin{tabular}{llll}
\hline Model & \multicolumn{2}{c}{ Unstandardized } \\
Coefficients Beta & Sig \\
\hline Model 1 & 1.983 & 9.527 & 0.000 \\
(Constant) & 0.347 & 7.123 & 0.000 \\
Edu_Pjk & & & \\
\hline Model 2 & 1.436 & 6.837 & 0.000 \\
(Constant) & 0.575 & 12.442 & 0.000 \\
Edu_Pjk & 0.152 & 2.795 & 0.006 \\
ZKIK & & \\
\hline
\end{tabular}

Sumber : Lampiran 8

Tabel 4.4 dapat dibuat persamaan struktural sebagai berikut :

$\mathrm{ZKIK}_{\mathrm{it}}=1.983+0.347$ ZEdu_Pjk

(Model 1)

ZPth_Bayar_Pjk $\mathrm{it}_{\mathrm{t}}=1.436+0.575 \mathrm{ZEdu} \_\mathrm{Pjk} \mathrm{i}_{\mathrm{it}}+0.152 \mathrm{ZKIK}_{\mathrm{it}}$

(Model 2)

Berdasarkan persamaan diatas Model 1 dan Model 2, dapat diartikan hal-hal sebagai berikut:

Model 1:

1. Koefisien Konstanta

Berdasarkan hasil hipotesis, nilai konstanta sebesar 1.983, hasil ini menunjukkan apabila semua variabel independen bernilai nol, maka KIK perusahaan nilainnya sebesar 1.983 .

2. Koefisien Variabel $\mathrm{X}_{1}\left(\mathrm{ZEdu} \_\mathrm{Pjk}\right)$

Berdasarkan hasil uji hipotesis (t-test) variabel ZEdu_Pjk menunjukkan nilai dari t hitung sebesar 7.123dengan tingkat signifikansi sebesar 0.000 . 


\section{Model 2:}

\section{Koefisien Konstanta}

Berdasarkan hasil hipotesis, nilai konstanta sebesar 1.436, hasil ini menunjukkan apabila semua variabel independen bernilai nol, maka Kepatuhan Bayar Pajak nilainnya sebesar 1.436 .

\section{Koefisien Variabel $X_{1}\left(Z E d u \_P j k\right)$}

Berdasarkan hasil uji hipotesis (t-test) variabel ZEdu_Pjk menunjukkan nilai dari $\mathrm{t}$ hitung sebesar 12.442 dengan tingkat signifikansi sebesar 0.000 .

\section{Koefisien Variabel $\mathrm{X}_{2}\left(\mathrm{ZKIK}_{\mathrm{it}}\right)$}

Berdasarkan hasil uji hipotesis (t-test) variabel ZPth_Bayar_Pjk menunjukkan nilai dari t hitung sebesar 2.795 dengan tingkat signifikansi sebesar 0.006 .

Bedasarkan Tabel 4.4, dapat di kemukakan diagram jalur sebagai berikut:

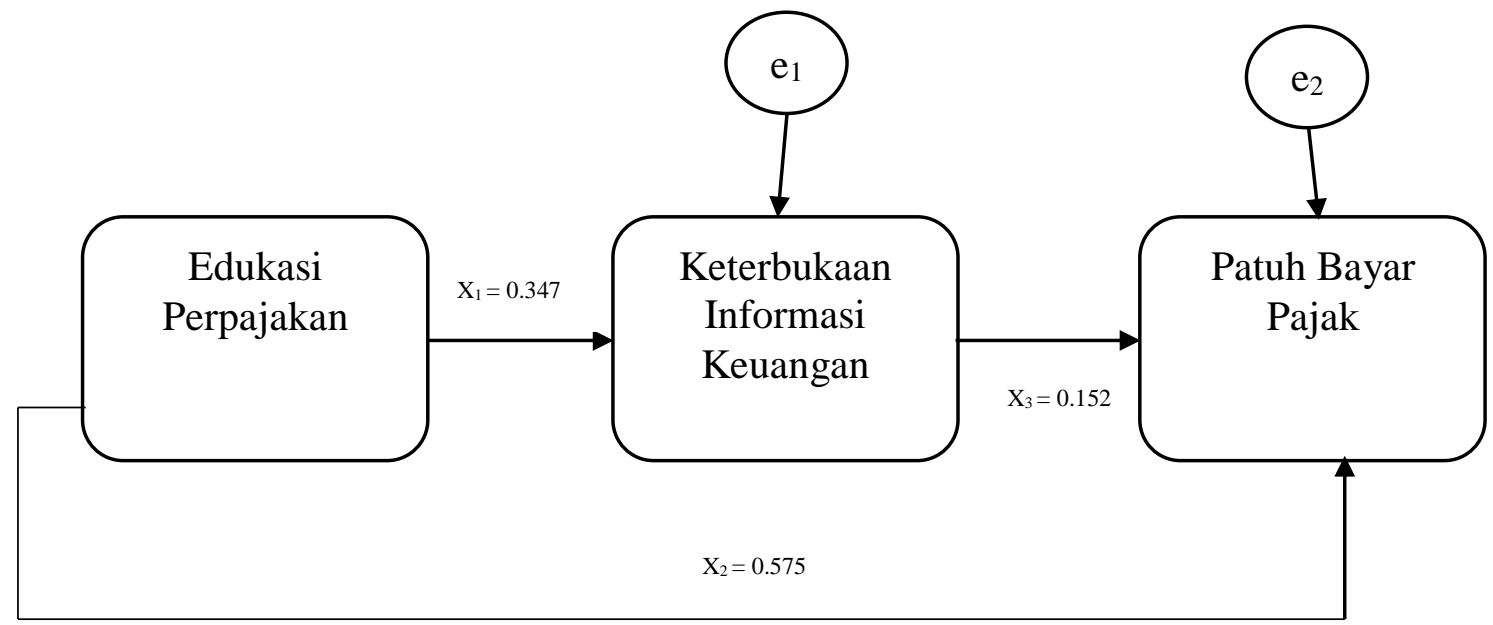

Gambar 4.1Analisis Jalur

Hasil analisis jalur menunjukkan bahwa Edukasi Perpajakan dapat berpengaruh langsung terhadap Keterbukaan Informasi Keuangan. Variabel Edukasi Perpajakan dan Undang-Undang Keterbukaan Informasi Keuangan dapat berpengaruh langsung dan tidak langsung terhadap PAtuh Bayar Pajak yaitu dari Edukasi Perpajakan ke Keterbukaan Informasi Keuangan (sebagai intervining) lalu ke Patuh Bayar Pajak. Besarnya pengaruh langsung Edukasi Perpajakan terhadap Keterbukaan Informasi Keuangan adalah 0.347, besarnya pengaruh langsung Edukasi Perpajakan terhadap Patuh Bayar Pajak adalah 0.575 sedangkan pengaruh tidak langsung harus dihitung dengan mengalikan koefisien tidak langsung (Ghozali, 242:2016) yaitu : 
1) Penaguruh tidak langsung Zkurs terhadap Zreturn saham $0.575 \times 0.152=0.0874$

Untuk mengetahui pengaruh mediasi signifikan atau tidak, maka di uji menggunakan Sobel test sebagai berikut (Ghozali, 242:2016):

1) Hitung standar error dari koefisien indirect effect $\left(S_{\mathrm{p} 2 \mathrm{p} 3 \mathrm{p} 4}\right)$

a. Pengaruh tidak langsung Edukasi Perpajakan terhada Patuh Bayar Pajak melalui Undang-Undang Keterbukaan Informasi Keuangan

$$
\begin{aligned}
& S p 2 p 3=\sqrt{p 3^{2} S p 2^{2}+p 2^{2} S p 3^{2}+S p 2^{2} S p 3^{2}} \\
& S p 2 p 3= \\
& \sqrt{(0.152)^{2}(0.049)^{2}+(0.347)^{2}(0.055)^{2}+(0.049)^{2}(0.055)^{2}} \\
& S p 2 p 3 \\
& =\sqrt{0.000055472704+0.000364237225+0.000007263025} \\
& S p 2 p 3=0.000426972954 \text { atau } 0.000
\end{aligned}
$$

Berdasarkan hasil diatas kemudian menghitung nilai t statistik pengaruh mediasi dengan rumus sebagai berikut:

a. Edukasi Perpajakan:

$$
t=\frac{p 2 p 3}{s p 2 p 3}=\frac{0.0874}{0.0004}=218.5
$$

Oleh karena nilai t hitung $=218.5$ lebih besar dari dari t tabel dengan tingkat signifikansi 0.05 yaitu sebesar 1.972, maka dapat disimpulkan bahwa koefisien mediasi 0.0874 signifikan yang berarti ada pengaruh mediasi.

\subsubsection{Uji Asumsi Klasik}

Uji asumsi klasik dilakukan untuk mengetahui penyimpangan yang terjadi pada data penelitian agar model path bersifat BLUE (Best Linier Unbiased Estimated). Asumsi klasik yang digunakan pada penelitan ini yaitu: uji multikolinieritas, Autokorelasi, dan Heteroskedastisitas yang secara rinci dijelaskan sebagai berikut: 


\section{Uji Multikolinieritas}

Multikolinieritas merupakan adanya hubungan linier diantara beberapa atau semua variabel independen pada model penelitian. Uji ini menentukan apakah pada model penelitian ditemukan hubungan linier antar variabel independen atau tidak. Cara mengetahui ada tidaknya multikolinieritas pada model dilakukan pendeteksian terlebih dahulu, kemudian jika multikolinieritas terjadi, barulah dilakukan tindakan untuk menghilangkan efek dari multikolinieritas (Gujarati, 2004:342-363).

Adapun cara untuk mengukur ada tidaknya multikolinieritas dapat dilihat dari nilai Tolerance (TOL) dan Variance Inflation Factors (VIF) dari masing masing variabel. Jika nilai VIF $\geq 10$ maka terjadi multikolinieritas dan sebaliknya (Gujarati, 2004). Hasil dari Uji Multikolinieritas disajikan pada Tabel berikut:

Tabel 4.5 Hasil Uji Multikolinieritas

\begin{tabular}{lllll}
\hline Variabel & Model 1 & & Model 2 \\
Independen & Y = KIK & & Y = Patuh Bayar Pajak \\
\hline & VIF & Kesimpulan & VIF & Kesimpulan \\
\hline
\end{tabular}

Pada Tabel 4.5, dapat diketahui nilai Varian Inflation Factor (VIF) semua variabel (ZKurs, ZSuku Bunga SBI, ZInflasi, dan ZROA) tidak mengalami multikolinieritas dengan nilai VIF $<10$ pada dua model diatas, maka variabel ini tidak teridentifikasi multikolinieritas.

\section{Uji Autokorelasi}

Uji autokorelasi digunakan untuk mengetahui ada tidaknya penyimpangan asumsi klasik, autokorelasi yaitu menguji korelasi yang terjadi antara residual pada satu pengamatan lain terhadap model regresi. Gejala autokorelasi dapat berakibat hasil regresi tidak efisien karena varian atau standart error of estimate tidak minimum dan menjadikan tes signifikansi tidak akurat. Cara mengetahui apakah model regresi mengandung autokorelasi dapat digunakan pendekatan Durbin Watson Test (Gujarati, 2004) dengan kriteria sebagai berikut:

a. Apabila $d_{U} \leq \mathrm{DW} \leq 4-d_{U} \cdot \mathrm{H}_{0}$ diterima, artinya tidak terdapat autokorelasi pada model tersebut. 
b. Apabila $\mathrm{DW} \leq d_{L} . \mathrm{H}_{0}$ ditolak, artinya terdapat autokorelasi pada model tersebut.

c. Apabila $\left(d_{L} \leq \mathrm{DW} \leq d_{U}\right)$ atau $\left(4-d_{L} \leq \mathrm{DW} \leq 4-d_{U}\right)$. Uji hasilnya konklusif, sehingga tidak dapat ditentukan apakah terdapat autokorelasi atau tidak.

Sebelum menganalisis hasil uji Durbin Watson, terlebih dahulu menentukan nilai batas atas $\left(d_{U}\right)$ dan batas bawah $\left(d_{L}\right)$. Tabel berikut menyajikan nilai $d_{L}$ dan $d_{U}$ sesuai dengan jumlah obeservasi penelitian :

Tabel 4.6 Nilai Batas Atas $\left(d_{U}\right)$ dan Batas Bawah $\left(d_{L}\right)$

\begin{tabular}{lllll}
\hline Jumlah Observas & $\begin{array}{l}\text { Variabel } \\
\text { Independen } \\
\text { (Model 1) }\end{array}$ & $\begin{array}{l}\text { Variabel } \\
\text { Independen } \\
\text { (Model 2) }\end{array}$ & \\
& $\mathrm{k}=1$ & & $d_{U}=1.778$ & $4-d_{U}=2.222$ \\
& & $d_{L}=1.758$ & $4-d_{L}=2.242$ \\
\hline $\mathrm{n}=254$ & $\mathrm{k}=2$ & $d_{U}=1.788$ & $4-d_{U}=2.212$ \\
& & $d_{L}=1.748$ & $4-d_{L}=2.252$
\end{tabular}

Sumber : Lampiran 11

Berdasarkan Tabel 4.6, jumlah observasi penelitian 254 dan Model 1, jumlah variabel independen 1 sehingga diperoleh nilai batas atas $\left(d_{U}\right)$ sebesar 1.778 dan nilai batas bawah $\left(d_{L}\right)$ sebesar 1.758. Model 2, jumlah variabel independen ada 2 sehingga diperoleh nilai batas atas $\left(d_{U}\right)$ sebesar 1.788 dan nilai batas bawah $\left(d_{L}\right)$ sebesar 1.748 . selanjutnya uji autokorelasi antar variabel ditunjukkan pada Tabel 4.12 berikut ini :

Tabel 4.7 Hasil Uji Autokorelasi

Model Penelitian

\section{Durbin- \\ Watson Kesimpulan}

Model 1 (Variabel Independ 1.950 Tidak Terdapat Autokorelasi

Edu_Pjk Dependen

Pth_Bayar_Pjk

Model 2 (Variabel Independe 1.854 Tidak Terdapat Autokorelasi

Edu_Pjk, KIK Dependen

Pth_Bayar_Pjk)

Sumber : Lampiran 11 
Pada Tabel 4.7, dapat di simpulkan bahwa model 1 memiliki nilai Durbin Watson 1.950 dan Model 2 memiliki nilai Durbin Watson 1.854. Nilai tersebut lebih tinggi dari nilai batas bawah $\left(d_{L}\right)$ namun lebih rendah dari nilai batas atas $\left(d_{U}\right)$ yaitu $1.758<1.950<2.222$ sehingga dapat disimpulkan tidak terdapat autokorelasi pada Model 1 dan Model 2 memiliki Durbin Watson 1.854. Nilai tersebut lebih tinggi dari nilai batas bawah $\left(d_{L}\right)$ namun lebih indah dari nilai batas atas $\left(d_{U}\right)$ yaitu $1.788<1.854<2.212$ sehingga dapat disimpulkan tidak terdapat autokorelasi.

\section{Uji Heteroskedastisitas}

Pengujian heteroskedastisitas adalah untuk menguji apakah dalam sebuah model regresi terjadi kesalahan penganggu yang mempunyai varian yang sama atau tidak. Pengujian ini menggunakan Glejser dengan langkah-langkah sebagai berikut (Gujarati, 2004:438):

a. Melakukan regersi variabel terikat $(\mathrm{Y})$ terhadap variabel bebas $(\mathrm{X})$ dan memperoleh nilai absolut residual.

b. Melakukan regersi variabel dari nilai absolut residual (lel) terhadap variabel bebas (X) dengan bentuk regresi sebagai berikut:

$$
\begin{aligned}
& \text { (lel) } Z=a_{0}+a_{0} X_{1}+a_{2} X_{2}+a_{3} X_{3}(\text { model } 1) \\
& \text { (lel) } Y=a_{0}+a_{0} X_{1}+a_{2} X_{2}+a_{3} X_{3}+a_{7} Z_{7}(\text { model } 2)
\end{aligned}
$$

Menentukan ada tidaknya heterokedastisitas dalam uji statistik untuk menguji hipotesis : $H_{a}: \mu=0$ dan $H_{i}: \mu \# 0$

Kriteria pengambilan keputusan dengan taraf signifikansi 5\% yaitu:

1. Apabila $p$-value $\geq 5 \%$, maka dalam model tidak terjadi heteroskedastisitas.

2. Apabila $p$-value $\leq 5 \%$, maka dalam model terjadi heteroskedastisitas.

Hasil dari Uji Heteroskedastisitas di sajikan pada tabel di bawah ini: 
Tabel 4.8 Hasil Uji Heteroskedastisitas

\begin{tabular}{lllll}
\hline \multirow{2}{*}{ Variabel } & Model 1 & \multicolumn{3}{c}{ Model 2 } \\
\cline { 2 - 4 } & P-value & Kesimpulan & P-value & Kesimpulan \\
\hline Edu_Pjk & 0.503 & Tidak mengalami & 0.600 & Tidak mengalami \\
& & heteroskedastisitas & & heteroskedastisitas \\
& & & 0.961 & Tidak mengalami \\
& & & heteroskedastisitas
\end{tabular}

Pada Tabel 4.8 diperoleh nilai signifikansi semua variabel eksogen pada Model 1 dan Model 2 lebih besar dari 0,05 (5\%), dapat disimpulkan bahwa $\mathrm{H}_{0}$ diterima, yang berarti Model 1 dan model 2 tidak mengalami heteroskedastisitas. Hal ini menunjukkan bahwa residual tidak mengandung heteroskedastisitas pada pada model path yang digunakan.

\subsubsection{Hasil Uji Hipotesis}

Analisis path digunakan untuk menguji besarnya kontribusi yang ditujukan oleh koefisien jalur pada setiap diagram jalur dari hubungan kausal antara variabel kurs, suku bunga SBI, inflasi terhadap ROA. Variabel kurs, suku bunga SBI, inflasi, ROA terhadap return saham. Digunakan untuk menganalisis hubungan sebab akibat yang terjadi jika variabel independennya mempengaruhi variabel dependen tidak hanya secara langsung melainkan secara tidak langsung. Penggunaan uji t pada dasarnya menunjukkan seberapa jauh pengaruh variabel penjelas atau independen secara individu dalam menerangkan variasi varaiabel dependen. Uji t digunakan untuk menguji hubungan pengaruh variabel independen dan dependen pada persamaan Model 1, dan Model 2.

Berdasarkan hasil perhitungan, akan diperoleh hasil analisis sebagaimana terlihat pada Tabel 4.9. 
Tabel 4.9 Hasil Uji Hipotesis $(\alpha=5 \%)$

\begin{tabular}{|c|c|c|c|c|}
\hline Variabel & Prediksi & Koefisien & Sig. & Kesimpulan \\
\hline \multicolumn{5}{|l|}{ Model 1 (Variabel } \\
\hline Dependen = Edu_Pjk) & & 1.983 & 0.000 & \\
\hline Pth_Bayar_Pjk & + & 0.347 & 0.000 & Signifikan \\
\hline \multicolumn{5}{|l|}{ Model 2 (Variabel } \\
\hline Dependen = KIK) & & 1.436 & 0,000 & \\
\hline Pth_Bayar_Pjk & + & 0.575 & 0,000 & Signifikan \\
\hline Edu_Pjk & + & 0.339 & 0,006 & Signifikan \\
\hline
\end{tabular}

Berdasarkan hasil pengujian pada Tabel 4.9, dapat dijelaskan hal - hal sebagai berikut:

a. Hipotesis pertama $\left(\mathrm{H}_{1}\right)$ menyatakan bahwa ZEdu_Pjk berpengaruh terhadap ZPth_Bayar_Pjk. Tabel 4.11 menunjukkan nilai koefisien path sebesar 1.983 mempunyai signifikansi yang lebih kecil dari $\alpha=5 \%(0.000<0.05)$. Nilai signifikansi lebih kecil dari 0.05 menunjukkan adanya pengaruh yang positif signifikan. Hal ini dapat diartikan bahwa terdapat pengaruh yang signifikan antara Edukasi Perpajakan terhadap Patuh Bayar Pajak. Bedasarakan keterangan diatas hipotesis 1 yang menyatakan Edukasi Perpajakan berpengaruh terhadap Patuh Bayar Pajak terbukti kebenarannya atau $\mathrm{H}_{\mathrm{a} 1}$ diterima.

b. Hipotesis kedua $\left(\mathrm{H}_{2}\right)$ menyatakan bahwa ZKIK berpengaruh terhadap ZPth_Bayar_Pjk. Tabel 4.11 membuktikan bahwa nilai koefisien path sebesar 0.575 mempunyai signifkansi 0.000 . Nilai signifikansi lebih kecil dari $\alpha=5 \%$ $(0.000<0.05)$ sehingga dapat dikatakan pengaruh positif tersebut signifikan, dengan kata lain terdapat pengaruh yang signifikan antara Patuh Bayar Pajak terhadap Keterbukaan Informasi Keuangan. Hipotesis kedua $\left(\mathrm{H}_{2}\right)$ yang menyatakan Keterbukaan Informasi Keuangan berpengaruh terhadap Patuh Bayar pajak terbukti kebenarannya atau $\mathrm{H}_{\mathrm{a} 2}$ diterima. 
c. Hipotesis ketiga $\left(\mathrm{H}_{3}\right)$ menyatakan bahwa ZEdu_Pjk berpengaruh terhadap ZKIK. Tabel 4.11 menunjukkan bahwa koefisien variabel Edukasi Perpajakan sebesar 0.339 dan nilai signifikansi lebih kecil dari $\alpha=5 \%(0.006<0.05)$, hal ini membuktikan bahwa Edukasi Perpajakan berpengaruh positif signifikan terhadap Keterbukaan Informasi Keuangan. Hipotesis ketiga $\left(\mathrm{H}_{3}\right)$ yang menyatakan Edukasi Perpajakan berpengaruh terhadap Keterbukaan Informasi Keuangan terbukti kebenarannya atau $\mathrm{H}_{03}$ diterima.

\subsection{Pembahasan}

\subsubsection{Pengaruh Edukasi Perpajakan Terhadap Kesadaran Bayar Pajak}

Hasil penelitian menunjukkan bahwa edukasi perpajakan memiliki pengaruh positif signifikan. Artinya, Ketika pemberian edukasi perpajakan meningkat maka kesadaran bayar pajak juga meningkat hal ini menunjukkan meningkatnya edukasi perpajakan,kesadaran masyarakat akan bayar pajak akan meningkat terutama dalam pemberian edukasi perpajakan dalam Perguruan Tinggi sehingga akan membuat pedapatan pemerintah dari sector pajak juga akan meningkat.

\subsubsection{Pengaruh Undang-Undang Keterbukaan Informasi Keuangan Terhadap Kesadaran Bayar Pajak}

Hasil penelitian menunjukkan bahwa Undang-Undang Keterbukaan Informasi Keuangan memiliki pengaruh positif yang signifikan terhadap Kesadaran Bayar Pajak. Artinya, dengan didapatkan akses Dirjen Pajak dalam dunia perbankan atau informasi dari lembaga keuangan lainya akan mampu membuat masyarakat jujur akan pendaptan dan asset yang dimiliki sehingga pengenaan pajak akan lebih valid dan adil.

\subsubsection{Pengaruh Edukasi Perpajakan Terhadap Kesadaran Bayar Pajak Melalui Undang- Undang Keterbukaan Informasi Keuangan}

Hasil penelitian menunjukkan bahwa Edukasi Perpajakan berpengaruh signifikan terhadap Patuh Bayar Pajak Melalui Undang-Undang Keterbukaan Informasi Keuangan. Artinya, Edukasi Perpajakan akan mempengaruhi Kepatuhan Membayar Pajak oleh masyarakat lebih kuat dengan di terapkannya Undang-Undang Keterbukaan Informasi Keuangan. 


\section{Kesimpulan}

Berdasarkan hasil dan pembahasan dapat disimpulkan bahwa responden 254 merupakan mahasiswa Program Studi Manajemen UST Yogyakarta tersebar dari angkatan 2017 sampai 2019 yang memberikan pernyataan bahwa adanya edukasi perpajakan sangat dibutuhkan oleh pihak mahasiswa untuk mendukung agar patuh pajak sejak dari dini. Adanya keterbukaan informasi keuangan juga memberikan pengaruh yang positif signifikan untuk upaya pemerintah agar masyarakat terutama mahasiswa agar patuh membayar pajak.

\section{DAFTAR PUSTAKA}

Halim Abdul, Icuk Rangga B, \& A. D. (2014). Perpajakan: Konsep, Aplikasi, Contoh, dan Studi Kausus. Jakarta: Salemba Empat.

Ihsan, M. (2013). Pengaruh Pengetahuan Wajib Pajak, Penyuluhan Pajak, Kualitas Pelayanan Pajak, Dan Pemeriksaan Pajak Terhadap Kepatuhan Wajib Pajak Badan Di Kota Padang. Universitas Negeri Padang.

Knut Eriksen, L. F. (1996). Tax Knowledge and Attitudes Towards Taxation; A Report on Quasi-Experiment. Journal of Economic Psychology, 387-402.

Mardiasmo. (2018). Perpajakan. Yogyakarta: Andi Publisher.

Nurmantu, S. (2005). Pengantar Perpajakan (Granit, ed.). Jakarta.

Ongkowijoyo, L. (2010). Analisis FaktorFaktor yang Mempengaruhi Kepatuhan Wajib Pajak Orang Pribadi Dalam Membayar Pajak Penghasilan. Universitas Brawijaya.

Purwono, H. (2010). Dasar-dasar Perpajakan \& Akuntansi Pajak. Jakarta: Erlangga.

Rahman, A. (2009). Hubungan Sistem Administrasi Perpajakan Modern dengan Kepatuhan Wajib Pajak. Jurnal Ilmu Administrasi, VI(1). 